\title{
Sintesis 2,5-bis(4-hidroksibensilidin) siklopentanon dari $p$-hidroksibenzaldehid dan Siklopentanon dengan Katalis Asam Sulfat
}

\section{Synthesis of 2,5-bis(4-hydroxybenzilidene) cyclopentanone from p-hydroxybenzaldehide and Cyclopentanone by Sulfuric Acid as a Catalyst}

\author{
Lusia Murtisiwi ${ }^{1 *}$ ) \\ 1) Akademi Farmasi Nasional Surakarta \\ * JL. Yos Sudarso No. 338 Surakarta, email : lusiasiwi@yahoo.co.id
}

\begin{abstract}
Abstrak
Senyawa 2,5-bis(4-hidroksibenzilidin)siklopentanon merupakan salah satu analog kurkumin. Penelitian ini bertujuan untuk mensintesis 2,5-bis(4-hidroksibenzilidin)siklopentanon dari $p$-hidroksibenzaldehid dan siklopentanon dengan katalis asam sulfat. Asam sulfat, suatu asam diprotik yang bersifat higroskopis diperkirakan dapat digunakan sebagai katalis dalam sintesis 2,5-bis(4hidroksibenzilidin)siklopentanon.

Penelitian ini merupakan penelitian eksploratif deskriptif non analitik dengan parameter penelitian berupa keberhasilan sintesis 2,5bis(4-hidroksibenzilidin)siklopentanon. Penelitian ini dilakukan dengan mereaksikan 0,06 mol $p$-hidroksibenzaldehid dan 0,03 mol siklopentanon dalam pelarut metanol dengan katalis asam sulfat. Analisis hasil penelitian dilakukan secara kualitatif meliputi uji organoleptis, uji kelarutan, pemeriksaan senyawa hasil sintesis dengan kromatografi lapis tipis (KLT), pemeriksaan titik lebur, elusidasi struktur senyawa hasil sintesis dengan spektroskopi inframerah (IR), spektroskopi resonansi magnetik inti proton ( $\left.{ }^{1} \mathrm{H}-\mathrm{NMR}\right)$ dan karbon-13 $\left({ }^{13} \mathrm{C}-\mathrm{NMR}\right)$. Sedangkan analisis hasil penelitian secara kuantitatif dilakukan dengan perhitungan rendemen senyawa hasil sintesis.

Hasil penelitian menunjukkan bahwa senyawa hasil sintesis berupa serbuk kuning, berbau khas, berasa khas. Titik lebur senyawa hasil sintesis $>300^{\circ} \mathrm{C}$. Pemeriksaan dengan KLT menunjukkan bercak senyawa hasil sintesis yang mempunyai $\mathrm{Rf}=0,73$, berbeda dengan $p$ hidroksibenzaldehid dengan $\mathrm{Rf}=0,84$. Elusidasi struktur dengan spektroskopi IR, spektroskopi ${ }^{1} \mathrm{H}-\mathrm{NMR}$, dan spektroskopi ${ }^{13} \mathrm{C}-\mathrm{NMR}$ menunjukkan spektra yang diidentifikasi sebagai senyawa yang memiliki struktur 2,5-bis(4-hidroksibenzilidin)siklopentanon menghasilkan rendemen sebesar $10,64 \%$.
\end{abstract}

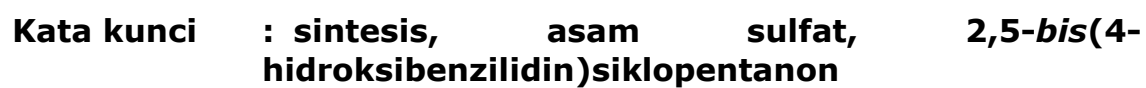

\section{Abstract}

2,5-bis(4-hydroxybenzilidene)cyclopentanone is one of curcumin analog compound. The aim of this research is to synthesize 2,5-bis(4-hydroxybenzilidene)cyclopentanone from $p$ hydroxybenzaldehyde and cyclopentanone using sulfuric acid as a catalyst. Persumably, sulfuric acid, a diprotic acid can be used as a catalyst in synthesizing 2,5-bis(4-hydroxybenzilidene)cyclopentanone. 
Sintesis 2,5-bis(4-hidroksibensilidin) siklopentanon dari $p$-hidroksibenzaldehid dan

Siklopentanon

The The research could be clasified as the descriptive explorative non-analytic research with the succedd of synthesizing of 2,5-bis(4hydroxybenzilidene)-cyclopentanone as the parameter. The research was done by reacting 0,06 mol p-hydroxybenzaldehyde and 0,03 mol cyclopentanone in methanol solution with sulfuric acid as a catalyst. The analysis was occupied with two ways, they were qualitative and quantitative. The qualitative analysis was done in a series of test. They were organoleptic test, solubility test, thin layer chromatography (TLC) test, melting point estimation, elucidation of synthesized compound with infra red (IR) spectroscopy, proton nuclear magnetic resonance $\left({ }^{1} \mathrm{H}\right.$-NMR) and carbon-13 nuclear magnetic resonance $\left({ }^{13} \mathrm{C}-\mathrm{NMR}\right)$ spectroscopy. The quantitative analysis was done by estimating the yield of synthesized compound.

The research result showed that synthesized compound was a yellowish powder, specified odor, tasteless but it has specified effect on tongue. The melting point of synthesized compound was more than $300^{\circ} \mathrm{C}$. The TLC test showed that synthesized compound has an Rf as much as 0,73 which was different with $p$-hydroxybenzaldehyde that was 0,84 . The IR, ${ }^{1} H$-NMR and ${ }^{13} \mathrm{C}-N M R$ spectra showed that the synthesized compound was 2,5-bis(4-hydroxybenzilidene)cyclopentanone with yield for about 10,64\%.

\section{Key words: synthesis, sulfuric acid, 2,5-bis(4- hydroxybenzilidene) cyclopentanone}

\section{Pendahuluan}

Kurkumin (gambar 1) merupakan senyawa antioksidan yang baik karena mampu menangkap radikal-radikal bebas seperti radikal hidroksil, anion superoksid, dan oksigen singlet dengan menginhibisi lipid peroksidase. Kurkumin juga menekan pertumbuhan sel kanker, diferensiasi, dan transformasi sel kanker. Kurkumin bekerja dengan menghambat protein kinase, biosintesis prostaglandin, dan aktivitas enzim siklooksigenase-2 (Ireson et al., 2002).

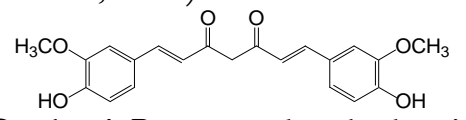

Gambar 1. Rumus struktur kurkumin

Hal ini mendorong berkembangnya sintesis turunan maupun analog kurkumin yang diharapkan mempunyai aktivitas yang setara atau lebih tinggi dari kurkumin. Sintesis analog atau turunan kurkumin dilakukan dengan modifikasi gugus, baik pada bagian terminal inti aromatik ataupun pada bagian tengahnya yaitu dengan mengubah bagian tengah menjadi bentuk siklik dan memendekkan rantai yang berada di tengah dengan menghilangkan satu gugus karbonil dan satu gugus metilen aktifnya (Sardjiman, 1997, cit Nugroho, 1998).

Telah diketahui bahwa kurkumin hanya stabil pada $\mathrm{pH}$ di bawah 6,5. Ketidakstabilan kurkumin di atas $\mathrm{pH}$ 6,5 karena adanya gugus metilen aktif. Penghilangan gugus metilen aktif dan satu gugus karbonil menjadi 1,4-pentadien-3on menghasilkan molekul yang lebih stabil dengan masih memiliki aktivitas antioksidannya (Sardjiman, 2000, cit Hakim, 2002).

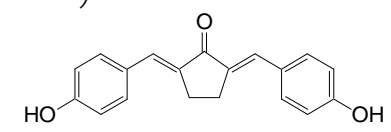

Gambar 2. Rumus struktur 2,5-bis(4-

hidroksibenzilidin)siklopentanon 2,5-bis(4-

hidroksibenzilidin)siklopenta-non merupakan salah satu senyawa analog kurkumin. Menurut Sardjiman (2000), senyawa ini mempunyai aktivitas antioksidan (inhibisi lipid peroksidase), antiinflamasi serta antibakteri gram positif khususnya Bacillus subtilis dan Streptococcus pneumoniae.

Senyawa 2,5-bis(4-hidroksibenzilidin) siklopentanon sebelumnya telah disintesis oleh Sardjiman (2000) dengan menggunakan katalis asam klorida. Asam 
klorida merupakan suatu asam monoprotik yang molekulnya hanya dapat menyumbangkan satu ion hidrogen ke molekul penerima, sedangkan asam sulfat merupakan asam diprotik yang dapat memberikan dua ion hidrogen ke molekul penerima. Kedua asam tersebut merupakan suatu asam kuat, tetapi asam sulfat yang merupakan asam diprotik dapat memprotonasi lebih sempurna. Selain itu asam sulfat mempunyai afinitas yang besar terhadap air, sehingga akan menggeser reaksi pembentukan 2,5-bis(4hidroksi-benzilidin) siklopentanon ke kanan dengan menarik air.

Berdasarkan sifat-sifat asam sulfat tersebut maka kemungkinan penggunaan asam sulfat sebagai katalis dalam sintesis 2,5-bis(4-hidroksi-benzilidin)

siklopentanon dapat mempercepat reaksi, namun belum diketahui keberhasilan sintesisnya. Oleh karena itu perlu dilakukan penelitian sintesis 2,5 - bis (4hidroksibenzilidin) siklopentanon menggunakan katalis asam lain yakni asam sulfat yang merupakan suatu asam diprotik.

\section{Metodologi}

\section{Bahan}

p-Hidroksibenzaldehid [kualitas p.a., Sigma-Aldrich, USA], etanol, metanol, etil asetat, aseton, asam asetat glasial, kloroform, benzena, asam sulfat [kualitas p.a., E-Merck], aquadest [lab. Kimia Farmasi Fak. Farmasi USD], trametilsilana atau TMS [kualitas p.a, EMerck], kertas saring, natrium bikarbonat, natrium hidroksida, asam klorida, kertas indikator universal [kualitas teknis], silika gel GF 254 dengan ketebalan $250 \mu \mathrm{m}$ [kualitas p.a, E-Merck].

Alat

Alat-alat gelas laboratorium, penangas es, termometer $360^{\circ} \mathrm{C}$, penangas mantel, stirrer, corong pisah, drupple plate, corong kaca, pompa vakum [Robinair, Model No. 15100], bejana untuk KLT, micro haematocrit tubes, micro pipet, lampu UV, pengering [Memmert Oven model 400], electrothermal capillary tubes neraca analitik [Precision Balance, Model GB3002, Mettler Toledo], spektrometer inframerah [Shimadzu FTIR-820IPC], spektrometer resonansi magnetik inti proton dan karbon-13 [HITACHI FTNMR R-1900], dan spektrometer UV/Vis [Perkin-Elmer Lambda 20/1,0 nm].

\section{A. Cara Kerja}

\section{Sintesis $2,5-b i s(4-$}

hidroksibenzilidin) siklopentanon

$\mathrm{Ke}$ dalam labu Erlenmeyer, dimasukkan $0,06 \quad$ mol $p$ hidroksibenzaldehid $(7,327 \mathrm{~g})$, dan 0,03 mol siklopentanon. Campuran tersebut kemudian dilarutkan dalam $15 \mathrm{ml}$ metanol, diletakkan dalam penangas es hingga suhu larutan mencapai $-5^{\circ} \mathrm{C}$ selama 10 menit. Kemudian ditambahkan 0,02 mol asam sulfat sebanyak $10 \mathrm{ml}$ tetes demi tetes selama 30 menit. Kemudian biarkan mencapai suhu kamar $\left(27^{\circ} \mathrm{C}\right)$ dan larutan diaduk dengan menggunakan stirrer magnetik dengan kecepatan pengadukan 250 rpm. Pengadukan dilakukan selama 5 jam 30 menit, kemudian larutan yang telah berubah warna menjadi merah disimpan pada suhu kamar selama 16 jam. Pengadukan dilanjutkan selama 4 jam 30 menit dengan kecepatan $400 \mathrm{rpm}$. Setelah itu larutan dinetralkan menggunakan larutan natrium bikarbonat dengan konsentrasi 0,3 N, endapan yang terjadi disaring kemudian dikeringkan dalam oven.

\section{Uji Pendahuluan terhadap Senyawa Hasil Sintesis}

a. Uji secara organoleptis. Senyawa hasil sintesis diuji secara organoleptis yang meliputi bentuk, warna, bau, dan rasa.

b. Uji kelarutan senyawa hasil sintesis. Sebanyak kurang lebih $10 \mathrm{mg}$ kristal senyawa hasil sintesis dimasukkan ke dalam Erlenmeyer $250 \mathrm{ml}$, kemudian ditambahkan aquades menggunakan micropipet $0,01 \mathrm{ml}(10 \mu \mathrm{l})$, bila perlu digojog. Penambahan aquades berulang kali menggunakan micropipet hingga kristal tepat larut. Prosedur yang sama dilakukan untuk pelarut metanol, etanol, kloroform, benzena, etil asetat, eter, natrium 
hidroksida, asam klorida, dan aseton. Hal yang sama dilakukan terhadap $p$ hidroksibenzaldehid sebagai pembanding.

c. Uji fluoresensi senyawa hasil sintesis. Pada drupple plate, sedikit serbuk senyawa hasil sintesis dilarutkan dalam etanol kemudian diamati fluoresensinya di bawah sinar UV 254 dan $365 \mathrm{~nm}$.

\section{Pemurnian senyawa hasil sintesis}

Kristal hasil sintesis digerus dengan mortir dan dimaserasi dengan campuran asam asetat dengan air (1:1), kemudian disaring. Kristal yang diperoleh dicuci dengan etanol dingin dan kemudian dicuci dengan air panas hingga bau asam asetat hilang kemudian dikeringkan dalam oven pada suhu $50^{\circ} \mathrm{C}$.

\section{Pemeriksaan titik lebur senyawa hasil sintesis}

Sedikit kristal hasil sintesis diisikan ke dalam electrothermal capillary tubes, kemudian dimasukkan dalam alat pengukur titik lebur (thermophan), amati peleburan kristalnya dan catat waktu pertama kali melebur hingga kristal melebur semua dengan kenaikan suhu $2^{\circ} \mathrm{C}$ tiap menit.

\section{Pemeriksaan senyawa hasil sintesis dengan kromatografi lapis tipis}

Senyawa hasil sintesis dan $p$ hidroksibenzaldehid dilarutkan dalam etanol dengan konsentrasi 1\% kemudian ditotolkan pada lempeng silika gel GF 254 sebanyak $10 \mu \mathrm{l}$ dengan menggunakan micro baematocrit tubes. Pengembangan dilakukan dengan jarak rambat $15 \mathrm{~cm}$ dalam bejana yang berisi fase gerak kloroform:metanol (1:3). Bercak diamati di bawah sinar lampu UV $254 \mathrm{~nm}$. Harga Rf dihitung terhadap jarak pengembangan $15 \mathrm{~cm}$.

\section{Elusidasi struktur senyawa hasil} sintesis

Elusidasi struktur senyawa hasil sintesis dilakukan dengan spektroskopi inframerah, spektroskopi resonansi magnetik inti proton ( $\left.{ }^{1} \mathrm{H}-\mathrm{NMR}\right)$, dan spektroskopi resonansi magnetik inti karbon-13 ( $\left.{ }^{13} \mathrm{C}-\mathrm{NMR}\right)$. Prinsip kerjanya adalah sebagai berikut:

a. Metode spektroskopi inframerah. Sebanyak kurang lebih 0,5-1 mg sampel dicampur homogen dengan kurang lebih 100 mg KBr, kemudian dikempa dan dibuat tablet. Cahaya infra merah dari sumber dilewatkan melalui cuplikan, kemudian dipecah menjadi frekuensifrekuensi individunya dalam monokromator. Intensitas relatif dari frekuensi individu diukur oleh detektor hingga didapat spektra infra merah dari senyawa tersebut.

b. Metode spektroskopi resonansi magnetik inti. Sebanyak kurang lebih 10-50 mg sampel dimasukkan ke dalam tabung dan tambahkan pelarut DMSO-d6 yang mengandung tetrametilsilana (TMS) sebagai standar internal. Sel sampel berupa tabung gelas kecil silindris diletakkan di antara kutub-kutub magnet. Sel sampel dipusingkan maka akan didapatkan resonansi proton dari spektrometer resonansi magnetik inti. Prosedur yang sama juga dilakukan dalam elusidasi struktur dengan spektroskopi resonansi magnetik inti karbon-13. Kekuatan spektrometer resonansi magnetik inti yang digunakan adalah 90 $\mathrm{MHz}$.

\section{Penentuan panjang gelombang} dengan serapan maksimal senyawa hasil sintesis

Senyawa hasil sintesis dengan konsentrasi $0,001 \% \mathrm{~b} / \mathrm{v}$ dalam etanol ditentukan panjang gelombang dengan serapan maksimalnya. Etanol digunakan sebagai blanko.

\section{B. Analisa Data}

1. Data organoleptis meliputi warna, bentuk, bau dan rasa

2. Data uji kelarutan senyawa hasil sintesis

3. Data uji fluoresensi senyawa hasil sintesis

4. Pemeriksaan kemurnian senyawa hasil sintesis berdasarkan :
a. Data kromatografi lapis tipis
b. Data titik lebur

5. Identifikasi struktur senyawa hasil sintesis berdasarkan
a. Spektra inframerah
b. Spektra resonansi magnetik inti proton (1H-NMR)


c. Spektra resonansi magnetik inti karbon-13 (13C-NMR)

6. Perhitungan rendemen

Rendemen $=$

$\frac{\text { berat senyawa hasil sintesis percobaan }}{\text { berat }} x 100 \%$

\section{Hasil dan Pembahasan}

\section{A. Sintesis 2,5-bis(4-hidroksi benzilidin)siklopentanon}

Sintesis

hidroksibenzilidin)

2,5-bis $(4-$

siklopentanon

didasarkan pada reaksi kondensasi aldol, dengan mereaksikan suatu aldehid yaitu phidroksibenzaldehid dan suatu keton yang mempunyai hidrogen $\alpha$ terhadap gugus pengaktif yaitu siklopentanon dalam pelarut metanol menggunakan katalis asam sulfat.

Reaksi kondensasi aldol pada sintesis 2,5-bis(4-hidroksibenzilidin)siklopentanon tahap pertama merupakan pembentukan enol (gambar 3) dan protonasi gugus karbonil dari $p$ hidroksibenzaldehid (gambar 4).

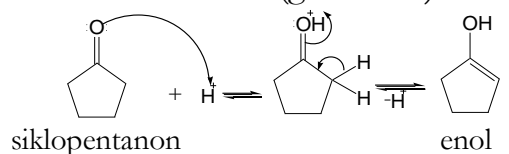

siklopentanon

Gambar 3. Pembentukan enol

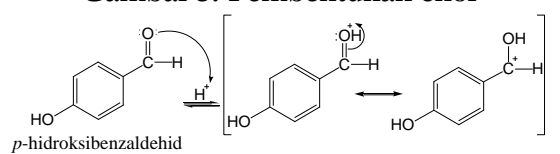

Gambar 4. Protonasi gugus karbonil dari phidroksibenzaldehid

Pada tahap pertama, atom oksigen dari siklopentanon mengalami protonasi oleh katalis asam sulfat dan melepaskan satu hidrgen $\alpha$ membentuk suatu enol, sedangkan $p$-hidroksibenzaldehid mengalami protonasi sehingga semakin mudah diserang oleh nukleofil seperti enol. Reaksi tahap kedua adalah adisi nukleofilik (enol) terhadap $p$ hidroksibenzaldehid terprotonasi membentuk suatu aldol (gambar 5). Pada tahap ketiga, aldol yang terbentuk mengalami dehidrasi melepaskan satu molekul air (gambar 6).

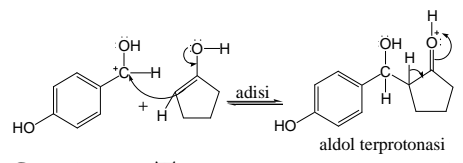

Gambar 5. Tahap adisi nukleofilik

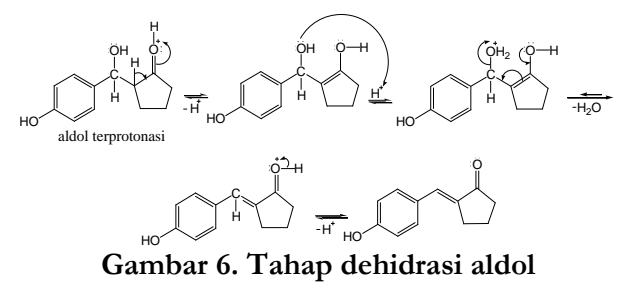

Produk yang terbentuk setelah dehidrasi aldol akan terprotonasi lagi membentuk enol dan mengalami tahaptahap reaksi kondensasi aldol kembali sampai terbentuk 2,5-bis(4hidroksibenzilidin) siklopentanon.

Waktu yang diperlukan dalam sintesis 2,5-bis(4-hidroksibenzilidin)siklopentanon dengan katalis asam sulfat secara keseluruhan adalah dua puluh enam jam, relatif lebih cepat daripada menggunakan katalis asam klorida yang memerlukan waktu sintesis secara keseluruhan selama lima puluh jam. Hal ini dikarenakan sifat asam sulfat yang lebih reaktif dan mempunyai afinitas yang besar terhadap air daripada asam klorida sehingga reaksi akan terus digeser ke kanan.

Keberhasilan sintesis dapat diketahui dari perhitungan rendemen. Sintesis 2,5-bis(4hidroksibenzilidin)siklopentanon dengan katalis asam sulfat menghasilkan rendemen relatif kecil yaitu 10,64\%. Hal ini dikarenakan penggunaan asam diprotik yaitu asam sulfat sebagai katalis dalam sintesis mengakibatkan kelimpahan proton yang sangat besar sehingga diduga meningkatkan terbentuknya enol dan bentuk siklopentanon terprotonasi. Enol dari siklopentanon yang terbentuk ini mengadisi bentuk siklopentanon terprotonasi. Hal ini menyebabkan terjadinya reaksi samping yaitu reaksi kondensasi diri antar molekul siklopentanon (gambar 7) membentuk hasil samping yang terlihat sebagai serbuk berwarna hijau kehitaman. 


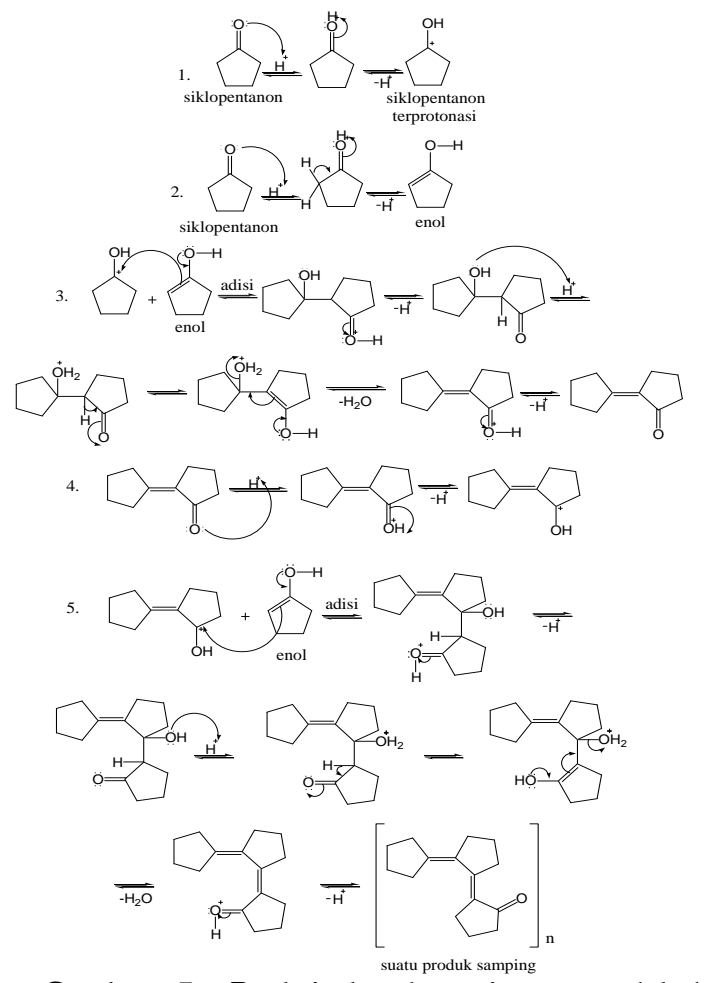

Gambar 7. Reaksi kondensasi antarmolekul siklopentanon

\section{Uji organoleptis}

\section{B. Uji Pendahuluan}

Uji organoleptis dilakukan untuk membandingkan sifat organoleptis senyawa hasil sintesis dengan starting materialnya. Hasil pemeriksaan organoleptis senyawa hasil sintesis dengan p-hidroksibenzaldehid sebagai pembanding ditunjukkan dalam tabel I.

Tabel I. Hasil uji organoleptis senyawa hasil sintesis dan $p$-hidroksibenzaldehid

\begin{tabular}{ccc}
\hline $\begin{array}{c}\text { Sifat organo- } \\
\text { leptis }\end{array}$ & $\begin{array}{c}\text { Senyawa } \\
\text { hasil sintesis }\end{array}$ & $\begin{array}{c}p \text { - } \\
\text { Hidroksibenzal- } \\
\text { dehid }\end{array}$ \\
\hline Bentuk & Serbuk & Kristal mengkilat \\
\hline Warna & Kuning & Putih kecoklatan \\
\hline Bau & Khas & $\begin{array}{c}\text { Bau tidak } \\
\text { enak,menyengat }\end{array}$ \\
\hline Rasa & Khas & Asam agak pahit \\
\hline
\end{tabular}

Berdasarkan hasil pemeriksaan organoleptis tersebut, dapat dikatakan bahwa senyawa hasil sintesis mempunyai sifat-sifat organoleptis yang berbeda dengan $\quad$-hidroksibenzaldehid pembandingnya.

\section{Uji kelarutan senyawa hasil sintesis}

Hasil uji kelarutan senyawa hasil sintesis dan $p$-hidroksibenzaldehid sebagai pembanding ditunjukkan dalam tabel II.

Tabel II. Hasil uji kelarutan senyawa hasil sintesis dan $p$-hidroksibenzaldehid sebagai pembanding

\begin{tabular}{|c|c|c|}
\hline Pelarut & $\begin{array}{c}\text { Senyawa hasil } \\
\text { sintesis }\end{array}$ & $\begin{array}{c}p- \\
\text { Hidroksibenzald } \\
\text { ehid }\end{array}$ \\
\hline Air & $\begin{array}{c}\text { Sangat sukar larut } \\
(1: 10000)\end{array}$ & $\begin{array}{c}\text { Agak sukar larut } \\
(1: 39)\end{array}$ \\
\hline Air panas & $\begin{array}{l}\text { Sangat sukar } \\
\text { larut }(1: 3000)\end{array}$ & $\begin{array}{c}\text { Agak sukar larut } \\
(1: 40)\end{array}$ \\
\hline Metanol & $\begin{array}{c}\text { Sukar larut } \\
(1: 406)\end{array}$ & $\begin{array}{c}\text { Sangat mudah } \\
\text { larut }(1: 0,8)\end{array}$ \\
\hline Etanol & Mudah larut (1:1) & Mudah larut (1:3) \\
\hline Kloroform & $\begin{array}{c}\text { Sangat sukar larut } \\
(1: 2600)\end{array}$ & $\begin{array}{c}\text { Mudah larut } \\
(1: 10)\end{array}$ \\
\hline Etil asetat & $\begin{array}{c}\text { Sukar larut } \\
(1: 573)\end{array}$ & Mudah larut (1:1) \\
\hline Benzena & $\begin{array}{c}\text { Sangat sukar larut } \\
(1: 1150)\end{array}$ & Larut $(1: 20)$ \\
\hline Eter & $\begin{array}{c}\text { Sukar larut } \\
(1: 584)\end{array}$ & Mudah larut (1:3) \\
\hline $\mathrm{NaOH} 0,1 \mathrm{~N}$ & Larut $(1: 11,5)$ & $\begin{array}{c}\text { Agak sukar larut } \\
(1: 80)\end{array}$ \\
\hline $\mathrm{HCl} 0,3 \mathrm{~N}$ & $\begin{array}{c}\text { Sangat sukar larut } \\
(1: 1000)\end{array}$ & $\begin{array}{c}\text { Agak sukar larut } \\
(1: 40)\end{array}$ \\
\hline Aseton & $\begin{array}{c}\text { Agak sukar larut } \\
(1: 86,2)\end{array}$ & Mudah larut $(1: 2)$ \\
\hline
\end{tabular}

Berdasarkan hasil uji kelarutan, maka dapat dikatakan bahwa senyawa hasil sintesis mempunyai sifat kelarutan yang berbeda dengan $p$ hidroksibenzaldehid.

3. Uji fluoresensi senyawa hasil sintesis

Dari hasil uji fluoresensi yang dilakukan, senyawa hasil sintesis yang dilarutkan dalam etanol berfluoresensi pada sinar UV $365 \mathrm{~nm}$, terlihat sebagai fluoresensi warna kuning. Hal ini disebabkan oleh adanya gugus kromofor yang relatif panjang dan auksokrom dari senyawa hasil sintesis. Selain itu senyawa hasil sintesis mempunyai struktur yang planar dan bersifat rigid serta mempunyai elektron bebas sehingga dapat tereksitasi oleh adanya sinar UV.

\section{Pemeriksaan Titik Lebur Senyawa Hasil Sintesis}

Pemeriksaan titik lebur dilakukan untuk mengetahui kemurnian senyawa 


\section{Lusia Murtisiwi}

hasil sintesis. Dari pemeriksaan titik lebur yang dilakukan, senyawa hasil sintesis mempunyai titik lebur $>300^{\circ} \mathrm{C}$, jauh lebih tinggi daripada p-hidroksibenzaldehid yang mempunyai titik lebur $116^{\circ} \mathrm{C}$, dengan demikian senyawa hasil sintesis bukan lagi p-hidroksibenzaldehid.

\section{Pemeriksaan Senyawa Hasil Sintesis dengan Kromatografi Lapis Tipis}

Kemurnian senyawa hasil sintesis dapat diidentifikasi dengan kromatografi lapis tipis (KLT). Dalam pemeriksaan ini, sebagai senyawa pembandingnya digunakan salah satu starting material yaitu p-hidroksi-benzaldehid.

Sistem kromatografi yang digunakan dalam pemeriksaan KLT ini merupakan sistem kromatografi normal dengan fase diam bersifat lebih polar daripada fase geraknya.

Senyawa hasil sintesis dan $p$ hidroksibenzaldehid sebagai pembanding tidak berfluoresensi di bawah sinar UV $254 \mathrm{~nm}$ sehingga digunakan fase diam silika gel GF 254. Silika gel GF 254 mengandung indikator fluoresensi sehingga dengan adanya bercak sampel maupun pembanding akan mengalami peredaman. Hal ini menyebabkan terlihatmya bercak padam dengan latar belakang fluoresensi hijau terang. Peredaman ini terjadi karena senyawa hasil sintesis dan pembandingnya mempunyai ikatan rangkap terkonjugasi dan gugus kromofor sehingga sinar UV tidak dapat mencapai indikator fluoresensi dan tidak ada cahaya yang dapat dipancarkan pada bercak tersebut.

Hasil pemeriksaan senyawa hasil sintesis dengan KLT ini dapat dilihat pada gambar 8.

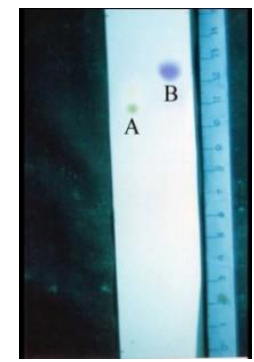

Gambar 8. Kromatogram senyawa hasil sintesis Keterangan: A: bercak senyawa hasil sintesis B: bercak $p$-hidroksibenzaldehid

Dari hasil pemeriksaan ini, dapat dikatakan bahwa senyawa hasil sintesis sudah berbeda dengan $p$ hidroksibenzaldehid. Bercak dari kedua senyawa merupakan bercak tunggal yang menunjukkan bahwa senyawa tersebut murni secara KLT.

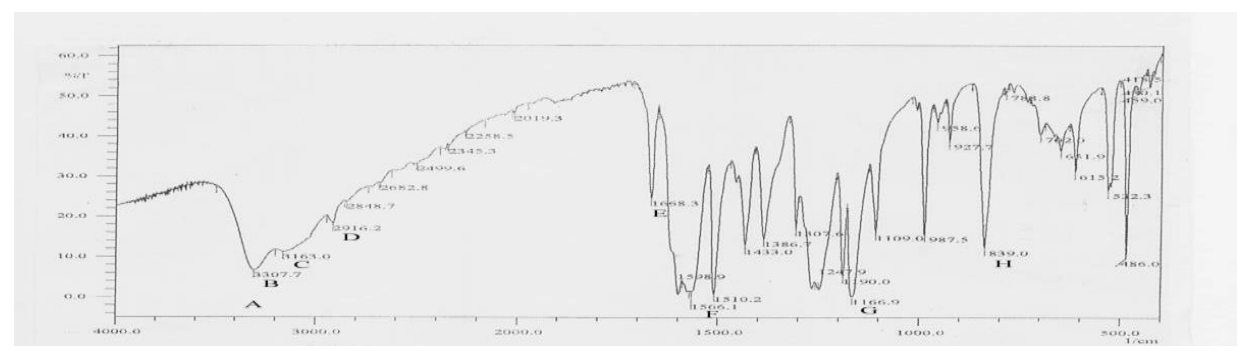

Gambar 9. Spekra inframerah senyawa hasil sintesis dalam KBr pelet

\section{Keterangan:}

A. Pita lebar pada $3600-3000 \mathrm{~cm}^{-1}$ menunjukkan adanya gugus $-\mathrm{OH}$ yang didukung adanya pita $\mathrm{B}$ yaitu pita vibrasi ulur pada $3307 \mathrm{~cm}^{-1}$

C. Pita vibrasi ulur pada $3163 \mathrm{~cm}^{-1}$ menunjukkan adanya gugus $\mathrm{C}-\mathrm{H}$ aromatik

D. Pita vibrasi ulur pada $2916 \mathrm{~cm}^{-1}$ menunjukkan adanya gugus $\mathrm{C}-\mathrm{H}$ alifatik

E. Pita vibrasi tekuk pada $1668 \mathrm{~cm}^{-1}$ menunjukkan gugus $\mathrm{C}=\mathrm{C}$ (alkena)

F. Pita vibrasi ulur pada $1566 \mathrm{~cm}^{-1}$ menunjukkan gugus $\mathrm{C}=\mathrm{O}(\alpha, \beta$ tidak jenuh)

G. Pita vibrasi ulur pada $1166 \mathrm{~cm}^{-1}$ menunjukkan gugus $\mathrm{C}-\mathrm{O}$

H. Pita vibrasi tekuk berintensitas kuat pada $839 \mathrm{~cm}^{-1}$ menunjukkan benzena tersubstitusi para 


\section{E. Elusidasi Struktur Senyawa Hasil Sintesis}

1.Interpretasi spektroskopi inframerah

Gugus-gugus fungsional pada suatu senyawa dapat diidentifikasi dengan spektroskopi inframerah (IR). Hasil elusidasi struktur dengan spektroskopi IR ditunjukkan pada gambar 9 untuk senyawa hasil sintesis, gambar 10 untuk $p$ hidroksibenzaldehid dan gambar 11 untuk siklopentanon. Tabel IV menunjukkan data hasil interpretasi spektra IR senyawa hasil sintesis dengan $p$ hidroksibenzaldehid dan siklopentanon sebagai pembanding.

Tabel III menunjukkan hasil interpretasi spektra IR dari senyawa hasil sintesis, $p$-hidroksibenzaldehid dan siklopentanon.

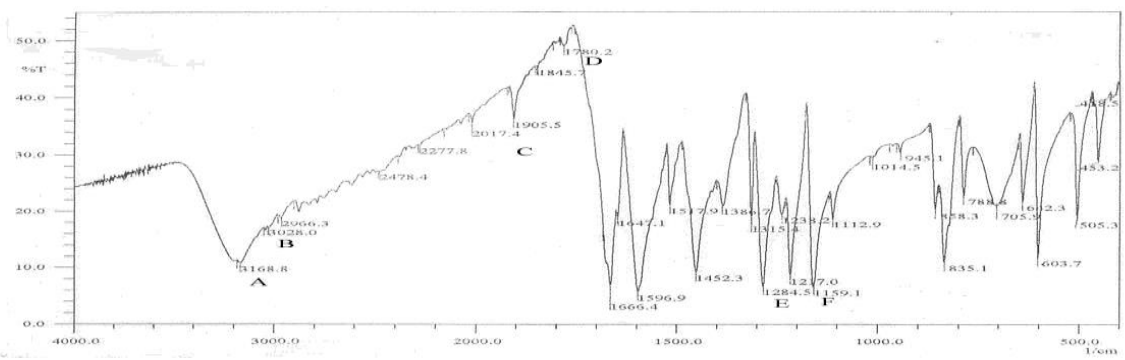

Gambar 10. Spektra inframerah $p$-hidroksibenzaldehid dalam $\mathrm{KBr}$ pelet

Keterangan:

A. Pita vibrasi ulur pada $3168 \mathrm{~cm}^{-1}$ menunjukkan gugus $-\mathrm{OH}$ yang didukung adanya pita lebar pada $3600-3000 \mathrm{~cm}^{-1}$

B. Pita vibrasi ulur pada $3028 \mathrm{~cm}^{-1}$ menunjukkan gugus $\mathrm{C}-\mathrm{H}$ aromatik

C. Pita vibrasi tekuk pada $2000-1700 \mathrm{~cm}^{-1}$ yang overtone dengan pita $\mathrm{F}$ pada $835 \mathrm{~cm}^{-1}$ menunjukkan benzena tersubstitusi para

D. Pita vibrasi tekuk pada $1780 \mathrm{~cm}^{-1}$ menunjukkan gugus $\mathrm{C}=\mathrm{O}$ aldehida

E. Pita vibrasi tekuk berintensitas kuat pada $1284 \mathrm{~cm}^{-1}$ menunjukkan gugus aldehida aromatik yang didukung adanya pita $\mathrm{F}$ yang berintensitas kuat pada $1159 \mathrm{~cm}^{-1}$

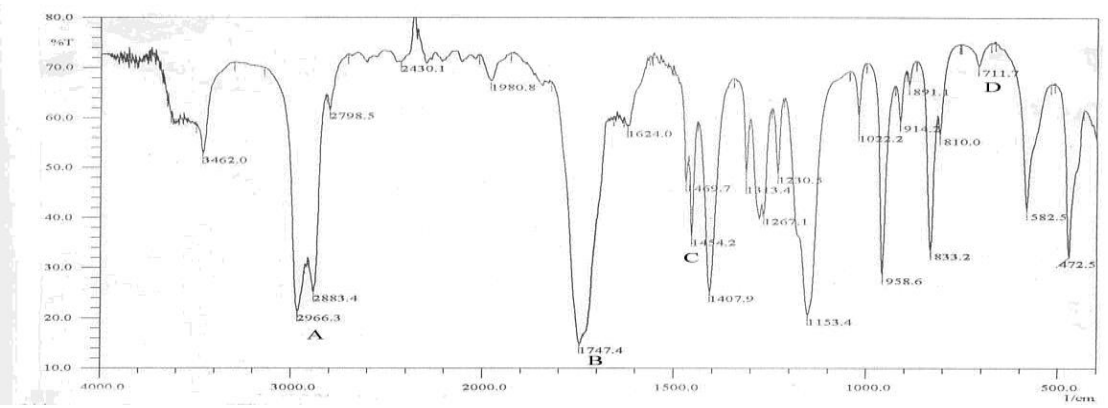

Gambar 11. Spektra inframerah siklopentanon dalam KBr pelet

Keterangan:

A. Pita vibrasi tekuk pada 2966 dan $2883 \mathrm{~cm}^{-1}$ menunjukkan adanya gugus siklik lima anggota

B. Pita vibrasi tekuk pada $1747 \mathrm{~cm}^{-1}$ menunjukkan gugus $\mathrm{C}=\mathrm{O}$ keton siklik

C. Pita vibrasi tekuk pada $1454 \mathrm{~cm}^{-1}$ menunjukkan gugus $-\mathrm{CH}_{2^{-}}$(metilen)

D. Pita vibrasi tekuk berintensitas lemah pada $711 \mathrm{~cm}^{-1}$ menunjukkan empat gugus metilen $\left(-\mathrm{CH}_{2}-\right)_{4}$ 


\section{Lusia Murtisiwi}

Tabel III. Hasil interpretasi spektra IR senyawa hasil sintesis, $p$-hidroksibenzaldehid dan siklopentanon

\begin{tabular}{cccc}
\hline $\begin{array}{c}\text { Gugus } \\
\text { fungsional }\end{array}$ & $\begin{array}{c}\text { Senyaw } \\
\text { a hasil } \\
\text { sintesis }\end{array}$ & $\begin{array}{c}p \text { - } \\
\text { Hidroksi } \\
\text { benzalde } \\
\text { hid }\end{array}$ & $\begin{array}{c}\text { Siklopen } \\
\text { tanon }\end{array}$ \\
\hline -OH aromatik & $(+)$ & $(+)$ & $(-)$ \\
\hline $\mathrm{C}=\mathrm{O}$ aldehida & $(-)$ & $(+)$ & $(-)$ \\
\hline $\mathrm{C}=\mathrm{O}$ keton & $(+)$ & $(-)$ & $(+)$ \\
\hline $\mathrm{C}-\mathrm{H}$ aromatik & $(+)$ & $(+)$ & $(-)$ \\
\hline$\left(-\mathrm{CH}_{2}-\right)_{4}$ & $(-)$ & $(-)$ & $(+)$ \\
\hline $\mathrm{C}=\mathrm{C}($ alkena $)$ & $(+)$ & $(-)$ & $(-)$ \\
\hline $\mathrm{C}-\mathrm{H}$ alifatik & $(+)$ & $(-)$ & $(-)$ \\
\hline $\mathrm{C}=\mathrm{O}(\alpha, \beta$ tidak \\
jenuh) & $(+)$ & $(-)$ & $(-)$ \\
\hline $\mathrm{C}-\mathrm{O}$ & $(+)$ & $(+)$ & $(-)$ \\
\hline $\begin{array}{c}\text { Benzena } \\
\text { tersubstitusi } \\
\text { para }\end{array}$ & $(+)$ & $(+)$ & $(-)$ \\
\hline
\end{tabular}

Keterangan: (+): ada, (-): tidak ada

Dari hasil interpretasi spektra IR, senyawa hasil sintesis mempunyai gugus $\mathrm{OH}$ aromatik, C-H aromatik, benzena tersubstitusi para, gugus $\mathrm{C}-\mathrm{O}$, gugus keton terkonjugasi ikatan rangkap, $\mathrm{C}=\mathrm{C}$ (alkena), C-H alifatik, dan gugus siklik lima anggota. Dengan demikian dapat dikatakan bahwa senyawa hasil sintesis diperkirakan adalah 2,5-bis(4hidroksibenzilidin)siklopentanon.
2. Interpretasi resonansi magnetik inti

a. Spektroskopi NMR Proton $\left({ }^{1} \mathrm{H}-\right.$ NMR).

Dari spektra ${ }^{1} \mathrm{H}-\mathrm{NMR}$ dapat diperoleh informasi tentang tipe-tipe atom hidrogen serta lingkungan tipe atom hidrogen dalam suatu molekul senyawa organik. Spektra ${ }^{1} \mathrm{H}-\mathrm{NMR}$ dari senyawa hasil sintesis ditunjukkan dalam gambar 12.

Pada spektra ${ }^{1} \mathrm{H}-\mathrm{NMR}$ senyawa hasil sintesis dalam pelarut dimetilsulfoksida terdeuterisasi, terlihat muncul delapan sinyal, yaitu sinyal A, B, C, D, E, F, G, dan H. Perbandingan integral-integral dari atom-atom hidrogen dari senyawa hasil sintesis yang diperkirakan 2,5-bis(4-hidroksibenzilidin siklopentanon adalah 4:2:4:4:2 atau 2:1:2:2:1.

Penelusuran tipe-tipe proton dari senyawa hasil sintesis yang diperkirakan 2,5-bis(4-hidroksibenzilidin)

siklopentanon ditunjukkan dalam gambar 29.

Data hasil interpretasi spektra ${ }^{1} \mathrm{H}-$ NMR senyawa hasil sintesis ditunjukkan dalam tabel IV.

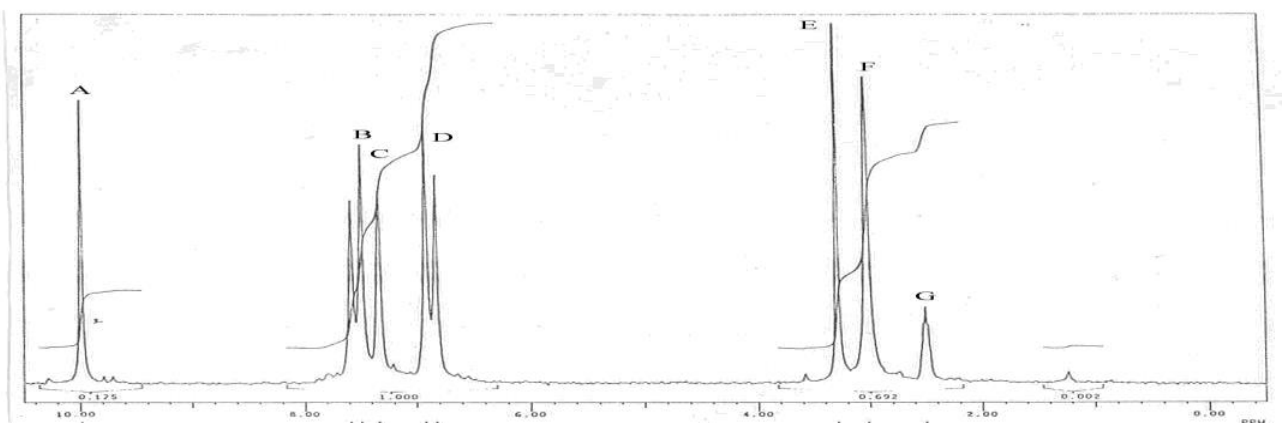

Gambar 12. Spektra ${ }^{1} \mathrm{H}-\mathrm{NMR}$ senyawa hasil sintesis dalam pelarut DMSO-d6

Keterangan:

A. Sinyal singlet integral satu pada $\delta 9,9 \mathrm{ppm}$ menunjukkan proton pada gugus hidroksi

B. Sinyal doblet integral dua pada $\delta 7,5 \mathrm{ppm}$ menunjukkan proton pada benzena tersubstitusi para

C. Sinyal singlet integral satu pada $\delta 7,3 \mathrm{ppm}$ menunjukkan proton pada benzena tersubstitusi para

D. Sinyal doblet integral dua pada $\delta 6,8 \mathrm{ppm}$ menunjukkan proton pada alkena tersubstitusi benzena

E. Sinyal singlet integral satu pada $\delta 3,3 \mathrm{ppm}$ menunjukkan proton dari air

F. Sinyal singlet integral dua pada $\delta 3,02 \mathrm{ppm}$ menunjukkan proton dari keton siklik

G. Sinyal singlet integral satu pada $\delta 2,5 \mathrm{ppm}$ menunjukkan proton pada gugus metil dari DMSO-d 6 Kekuatan NMR: 90 MHz. 


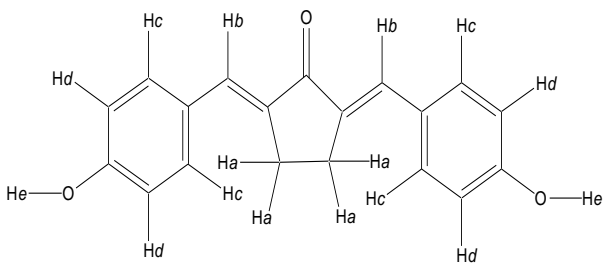

Gambar 13. Penelusuran tipe-tipe proton 2,5bis(4-hidroksibenzilidin)siklopentanon

Keterangan:

- Ha tidak mempunyai proton tetangga tak ekuivalen, menimbulkan sinyal singlet (sinyal F)

- Hb tidak mempunyai proton tetangga tak ekuivalen, menimbulkan sinyal singlet (sinyal C)

- Hc mempunyai satu proton tetangga tak ekuivalen yaitu $\mathrm{Hd}$, menimbulkan sinyal doblet (sinyal B)

- Hd mempunyai satu proton tetangga tak ekuivalen yaitu Hc, menimbulkan sinyal doblet (sinyal D)

- He tidak mempunyai proton tetangga tak ekuivalen, menimbulkan sinyal singlet (sinyal A)

Berdasarkan hasil interpretasi spektra ${ }^{1} \mathrm{H}-\mathrm{NMR}$, nampak bahwa senyawa hasil sintesis mempunyai tipe-tipe proton pada gugus hidroksi, benzena tersubstitusi para, proton terikat karbon alifatik tidak jenuh dan proton terikat karbon siklik keton.
Tabel IV. Hasil interpretasi spektra ${ }^{1} \mathrm{H}-\mathrm{NMR}$ dari senyawa hasil sintesis

\begin{tabular}{ccc}
$\begin{array}{c}\text { Jenis } \\
\text { Proton }\end{array}$ & Determinasi & $\begin{array}{c}\text { Senyawa } \\
\text { hasil sintesis }\end{array}$ \\
\hline $\begin{array}{c}\text { Benzena } \\
\text { tersubstitusi } \\
\text { para }\end{array}$ & $(+)$ \\
\hline $\begin{array}{c}\text { Gugus } \\
\text { hidroksi }\end{array}$ & & $(+)$ \\
Rantai \\
alifatik
\end{tabular}

Keterangan: (+): ada, (-): tidak ada

\section{b. Spektroskopi ${ }^{13}$ C-NMR.}

Spektra ${ }^{13} \mathrm{C}-\mathrm{NMR}$ dari senyawa hasil sintesis ditunjukkan dalam gambar 14.

Elusidasi struktur senyawa hasil sintesis dalam pelarut dimetilsulfoksida terdeuterisasi dengan spektroskopi NMR karbon-13 ( $\left.{ }^{13} \mathrm{C}-\mathrm{NMR}\right)$ dekoplining proton menghasilkan sembilan profil sinyal yaitu sinyal A, B, C, D, E, F, G, dan $\mathrm{H}$.

Penelusuran tipe-tipe karbon senyawa hasil sintesis yang diperkirakan merupakan 2,5-bis(4hidroksibenzilidin)siklopentanon ditunjukkan dalam gambar 15.

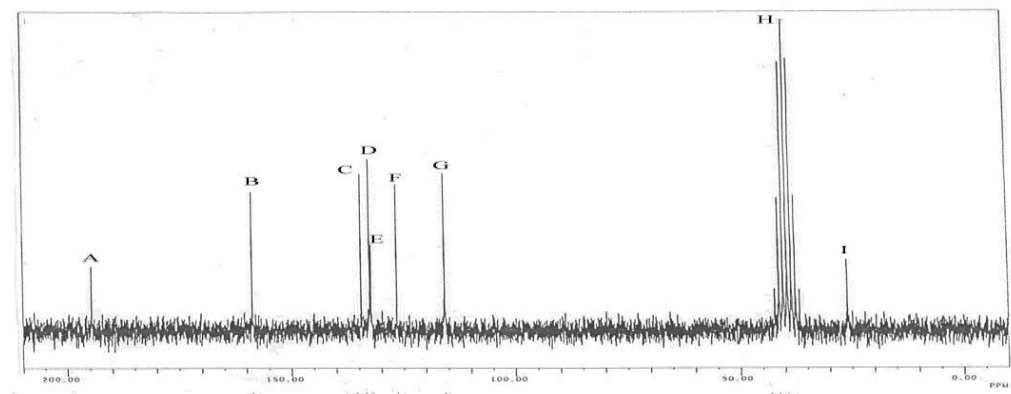

Gambar 14. Spektra ${ }^{13} \mathrm{C}-\mathrm{NMR}$ senyawa hasil sintesis dalam pelarut DMSO-d6

Keterangan:

A. Sinyal pada $\delta 194,5$ ppm menunjukkan karbon pada gugus karbonil

B. Sinyal pada $\delta 158,7 \mathrm{ppm}$ menunjukkan karbon pada benzena yang terikat dengan gugus hidroksi

C. Sinyal pada $\delta 134,4 \mathrm{ppm}$ menunjukkan karbon siklik terhibridisasi $\mathrm{sp}^{2}$

D. Sinyal pada $\delta 132,5 \mathrm{ppm}$ menunjukkan karbon alifatik tidak jenuh

E. Sinyal pada $\delta 132,1 \mathrm{ppm}$ menunjukkan karbon pada benzena tersubstitusi para

F. Sinyal pada $\delta 126,5 \mathrm{ppm}$ menunjukkan karbon pada benzena tersubstitusi para

G. Sinyal pada $\delta 115,7 \mathrm{ppm}$ menunjukkan karbon pada benzena tersubstitusi para

H. Sinyal pada $\delta 39,5 \mathrm{ppm}$ menunjukkan karbon dari dimetilsulfoksida terdeuterisasi

I. Sinyal pada $\delta 25,9 \mathrm{ppm}$ menunjukkan karbon siklik terhibridisasi $\mathrm{sp}^{3}$

Kekuatan ${ }^{13} \mathrm{C}$-NMR: $90 \mathrm{MHz}$. 


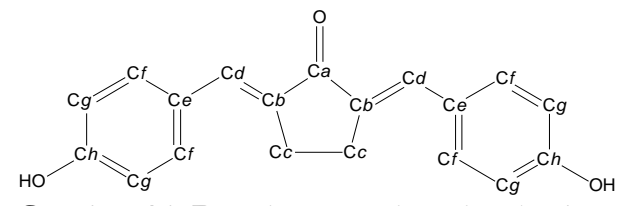

Gambar 15. Penelusuran tipe-tipe karbon 2,5-bis(4-hidroksibenzilidin)siklopentanon

Data hasil interpretasi spektra ${ }^{13} \mathrm{C}$ NMR senyawa hasil sintesis ditunjukkan dalam tabel V.

Tabel V. Hasil interpretasi spektra ${ }^{13} \mathrm{C}$-NMR senyawa hasil sintesis

\begin{tabular}{ccc}
\hline Jenis karbon & Determinasi & $\begin{array}{c}\text { Senyawa hasil } \\
\text { sintesis }\end{array}$ \\
\hline $\begin{array}{c}\text { Benzena } \\
\text { tersubstitusi para }\end{array}$ & $(+)$ \\
\hline Karbon karbonil & $(+)$ & $(+)$ \\
\hline $\begin{array}{c}\text { Karbon siklik } \\
\text { terhibridisasi } s p^{2}\end{array}$ & $(+)$ \\
\hline $\begin{array}{c}\text { Karbon alifatik } \\
\text { tidak jenuh }\end{array}$ & & \\
\hline Karbon siklik & & \\
terhibridisasi $s p^{3}$
\end{tabular}

Keterangan: (+):ada, (-): tidak ada

Berdasarkan hasil interpretasi spektra ${ }^{13} \mathrm{C}-\mathrm{NMR}$, terlihat bahwa senyawa hasil sintesis memiliki karbon karbonil, benzena tersubstitusi para, karbon siklik terhibridisasi $s p^{2}$, karbon alifatik terhibridisasi $s p^{2}$ dan karbon siklik terhibridisasi $s p^{3}$ sesuai dengan struktur 2,5-bis(4-hidroksibenzilidin)siklopentanon.

\section{F. Penentuan Panjang Gelombang dengan Serapan Maksimal Senyawa Hasil Sintesis}

Dari penentuan panjang gelombang maksimal yang dilakukan, $\lambda_{\text {maks }}$ senyawa hasil sintesis dalam etanol adalah 397,1 nm dengan serapan maksimal 0,338 . $\lambda_{\text {maks }}$ $397,1 \mathrm{~nm}$ ini termasuk pada daerah panjang gelombang UV meskipun senyawa hasil sintesis berwarna, tetapi dari spektra terlihat adanya pengekoran kurva ke daerah panjang gelombang visibel sehingga memberikan warna kuning.

\section{Kesimpulan}

Asam sulfat dapat digunakan sebagai katalis dalam sintesis 2,5-bis(4hidroksibenzilidin)siklopentanon menghasilkan rendemen 10,64\%.

\section{Daftar Pustaka}

Anonim, 1989, The Merck Index - An Encyclopedia of Chemicals, Drugs, and Biologicals, Eleventh Edition, 426, 763, Merck \& Co., Inc., Rahway. N.J., USA

Anonim, 1995, Farmakope Indonesia, Edisi IV, 1, Departemen Kesehatan Republik Indonesia, Jakarta

Bruice, P.Y., 1998, Organic Chemistry, 2 ${ }^{\text {nd }}$ edition, 953, 955-960, Prentice-Hall Inc, New Jersey

Fessenden, R.J. dan Fessenden, J.S., 1986a, Organic Chemistry, diterjemahkan oleh Aloysius Hadyana Pudjaatmaka, Edisi Ketiga, Jilid I, 315, 327-336, 340-357, Penerbit Erlangga, Jakarta

Fessenden, R.J. dan Fessenden, J.S., 1986b, Organic Chemistry, diterjemahkan oleh Aloysius Hadyana Pudjaatmaka, Edisi Ketiga, Jilid II, 1, 6, 163-165, 179, 184, 454462, Penerbit Erlangga, Jakarta

Gritter, Roy J, James M. Bobbitt, Arthur E. Schwarting, 1991, Pengantar Kromatografi, 107-110, Penerbit ITB, Bandung

Hakim, A.R., 2002, Sintesis Kurkumin, bis-demetoksikurkumin, bisdemetoksidehidroksikurkumin dan Pentagamavunon-0 serta Pengaruhnya terhadap Farmakokinetika Teofilin pada Tikus, Tesis, 55, Program Pasca Sarjana Universitas Gadjah Mada, Yogyakarta

Ireson, C. R., et al., 2002, Metabolism of The Cancer Chemopreventive Agent Curcumin in Human and Rat Intestine, 3-4, 
http://cebp.aacrjournals.org/cgi. Diakses pada 13 Mei 2004

Keenan, C.W., Donald C. Kleinfelter, Jesse H. Wood, 1980, General College Chemistry, diterjemahkan oleh Aloysius Hadyana Pudjaatmaka, Edisi Keenam, 593, Penerbit Erlangga, Jakarta

Nugroho, A.E., 1998, Sintesa 2,5-bis(4hidroksi-3-

metoksibenzilidin)siklopenta-non dengan Variasi Suhu $28^{\circ} \mathrm{C}, 38^{\circ} \mathrm{C}$, dan $48^{\circ} \mathrm{C}$ pada Fase Pengadukan, Skripsi,9-10, Fakultas Farmasi Universitas Gadjah Mada, Yogyakarta

Pavia, D.L., Lampman, G.M., Kriz Jr, G.S., 1976, Introduction to Organic Laboratory Techniques, 517, W. B Saunders Company, Philadelphia

Reksohadiprodjo, Moch. Samhoedi, 1996, Kuliah dan Praktika Kimia Farmasi Preparatif, volume 0, 7, 35-37, Fakultas Farmasi UGM, Yogyakarta

Sardjiman, 2000, Synthesis of Some New Series of Curcumin Analogues, Antioxidant, Anti-inflamatory,
Antibacterial Activities and Qualitative Structure-activity Relationship, Dissertation, 157, 184, 185, 193, Gadjah Mada University, Yogyakarta, Indonesia

Sastrohamidjojo, H., 1991, Spektroskopi Inframerah, cetakan pertama, 3-4, 1516, Penerbit Liberty, Yogyakarta

Sastrohamidjojo, H., 2001, Spektroskopi, cetakan kedua, 45-48, 52-54,99-100, 163, 178-181, Penerbit Liberty, Yogyakarta

Sherma, Joseph \& Bernard Fried, 1996, Handbook of Thin Layer Chromatography, $2^{\text {nd }}$ edition, volume 71, 102, Marcel Dekker.Inc, New York

Sykes, Peter., 1986, A Guidebook to Mechanism in Organic Chemistry, diterjemahkan oleh Anton J. Hartono dkk, edisi keenam, 296-297, Penerbit PT Gramedia, Jakarta

Yamamoto, Makoto., and Yamada, Kazutoshy., 1984, Organic Reaction Mechanism, diterjemahkan oleh Roos Koesno, dkk, 108-109, Chiba University, Japan 